\title{
膠芽腫の病態・治療と未来医療を見据えた研究の方向性
}

\author{
篠山 隆司，田中一寛 \\ 神戸大学大学院医学研究科外科系講座脳神経外科学分野
}

\section{Biology and Treatment of Glioblastoma: Future Direction of Basic Research}

\author{
Takashi Sasayama, M.D., Ph.D., and Kazuhiro Tanaka, M.D., Ph.D. \\ Department of Neurosurgery, Kobe University Graduate School of Medicine
}

Genetic/epigenetic analysis and transcriptome analysis using next-generation sequencing have revealed many of the biological characteristics of glioblastoma. In glioblastoma, three core pathway abnormalities: the receptor tyrosine kinase (RTK) pathway, the p53 pathway, and the retinoblastoma (RB) pathway, are the main abnormal pathways, and there are three subtypes: proneural, classical, and mesenchymal, depending on gene expression. However, a single-cell RNA-seq analysis revealed that there are various subtypes with different gene expressions within the same glioblastoma in the same patient. The results also showed that cell subtypes have plasticity that can be changed by genetic and chromosomal abnormalities and the microenvironment around the tumor. In addition, on recurrence after treatment, many glioblastomas have subtypes that are switched and have different properties. Currently, the main standard treatments for glioblastoma are surgery, radiation therapy, and chemotherapy. However, immunotherapy, including immune checkpoint inhibitors, is expected to be added in the future. It is very important to analyze the biological characteristics of the glioblastoma cells themselves. However, as a direction for future research, it will be necessary to longitudinally analyze the interaction between glioblastoma cells and the various cells that form the microenvironment, that is, immune cells, such as macrophages/microglia and lymphocytes, vascular endothelial cells, and neurons, in the context of the time axis.

(Received December 22, 2020 ; accepted February 9, 2021)

Key words : glioblastoma, biology, treatment

Jpn J Neurosurg（Tokyo） $30: 380-390,2021$

\section{はじめに}

2000 年にワインバーグらはがんの特徵的な性質 (がん のホールマーク) として，(1)増殖シグナルの立進，(2)血 管新生の充進, (3)増殖抑制の解除, (4)アポトーシスの抑 制，(5)無制限な複製による不死化，6浸潤や転移の促進

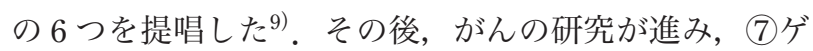
ノムの不安定性，8エネルギー代謝変化によるがん代
謝，(9)免疫回避，(10がん促進性炎症が加わった ${ }^{10)}$ 。膠芽 腫は他のがんと同様に上記の性質を合わせ持つが，米国 でのがんゲノムプロジェクトである TCGA（The Cancer Genome Atlas）は 3 つの経路の異常を有することを報告 した。つまり，細胞増殖・生存シグナルを司る RTK (receptor tyrosine kinase) 経路，アポトーシスを制御し たり，ゲノムの安定化を司る $p 53$ 経路，細胞周期の調整 を司る $R b$ (retinoblastoma) 経路の 3 つの経路の異常で

連絡先：篠山隆司， $=$ 650-0017 神戸市中央区楠町 7-5-1 神戸大学大学院医学研究科外科系講座脳神経外科学分野 Address reprint requests to : Takashi Sasayama, M.D., Department of Neurosurgery, Kobe University Graduate School of Medicine, 7-5-1 Kusunoki-cho, Chuo-ku, Kobe-shi, Hyogo 650-0017, Japan 
Table 1 Glioblastoma subtypes

\begin{tabular}{|c|c|c|c|}
\hline Genetic feature & TCGA subtype & miRNA-based subtype & $\begin{array}{l}\text { DNA methylation- } \\
\text { based subtype }\end{array}$ \\
\hline $\begin{array}{l}\text { PDGFRA mutation/amplification (high expres- } \\
\text { sion) } \\
\text { IDH mutation } \\
\text { p53 mutation } \\
\text { Often secondary glioblastoma }\end{array}$ & Proneural type & $\begin{array}{l}\text { Oligoneuronal precursor } \\
\text { type }\end{array}$ & $\begin{array}{l}\text { RTK1 (PDGFRA) type } \\
\text { IDH type }\end{array}$ \\
\hline $\begin{array}{l}\text { EGFR mutation/amplification(high expression) } \\
C D K N 2 A \text { deletion (RB pathway inactivation) } \\
\text { Chromosome } 7 \text { amplification } \\
\text { Chromosome } 10 \text { loss }\end{array}$ & Classical type & Radial glia type & RTK2 (classic) type \\
\hline $\begin{array}{l}\text { NF1 mutation (RAS/PI3K/Akt pathway activa- } \\
\text { tion) } \\
\text { PTEN mutation } \\
\text { High expression of YKL- } 40 \\
\text { High expression of MET }\end{array}$ & Mesenchymal type & Astrocyte precursors type & Mesenchymal type \\
\hline
\end{tabular}

ある ${ }^{3)}$ 。加えて他のがんと異なり, 膠芽腫は他臓器への 転移能力は著しく欠損している一方, 脳内への浸潤能は 際立っている。膠芽腫の性質は以前に比べるとかなり解 明されてきているが, 悪性化や治療抵抗性の機序, 治療 後の変化などまだ不明な点は多い。また，膠芽腫は腫瘍 細胞のみで形成されるのではなく，血管内皮細胞，血管 周皮細胞，マクロファージ/ミクログリアを中心とした 免疫細胞などさまざまな支持細胞, 免疫細胞とともに構 成されている。これらの細胞がどのように微小環境を構 築するのか, また, 治療によりどのように変化するのか など，解明すべき課題は多い. 今回，膠芽腫の病態，治 療と未来医療における研究の方向性について概説する.

\section{膠芽腫の病態}

\section{1 染色体・遺伝子異常, mRNA 発現によるサブタ イプ（TCGA サブタイプ）}

サブタイプ分類はかなり以前より試みられていたが, 2010 年に Verhaak ${ }^{38)}$ が 200 例以上の膠芽腫の染色体・ 遺伝子異常, mRNA 発現を詳細に解析し, proneural, neural, classical, mesenchymalの 4 つのサブタイプに分 類されることを報告した。 その後の解析で neural 夕イプ

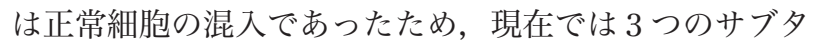
イプが定着している(Table 1). Proneural タイプはPDG$F R A$ の増幅・異常を特徴とし, p53 変異もこのタイプに 多く, しばしば $I D H$ 変異を伴い低悪性度グリオーマから 悪性化した二次性膠芽腫が多い. Classical 夕イプはしば しば 7 番染色体の増幅, 10 番染色体の欠失があり, $E G F R$ の无進, $C D K N 2 A / 2 B, P T E N$ の欠失を主な特徵と
する. Mesenchymal タイプは NF1 異常が多く，YKL-40 やMETの発現が立進していることが多い. Proneural 夕 イプは当初，他のタイプに比べて予後良好とされていた が，これは $I D H$ 変異がある腫瘍が含まれていたためであ り, IDH 変異のない proneural 夕イプの膠芽腫は他の夕 イプとほぼ同様に予後不良である。

\section{2 エピゲノムによるサブタイプ分類}

マイクロ RNA（microRNA：miR）は 20 塩基ほどの短 い non-coding RNA で,メッセンジャーRNA (mRNA) の 発現を調整する分子であり，がんの発生，悪性化，浸 潤・転移，血管新生にも関係する。膠芽腫でもさまざま な miR の発現異常を認め, miR-21 が膠芽腫で高度に発 現してアポトーシスを抑制することが 2005 年に最初に 報告された ${ }^{4)}$ ，その後すぐに網羅的な解析にて，膠芽腫 では正常脳に比較して miR-10b, miR-21， miR-25など が亢進し，miR-128 と miR-181a/181b-/181cなどが低下 していると報告された ${ }^{5)}$. 現在では, 幹細胞維持・分化, 代謝, 免疫回避, アポトーシスなど, 膠芽腫に特徵的な さまざまな miR 異常が明らかとなつている。また，膠芽 腫における $\mathrm{miR}$ の発現プロファイルは，放射状グリア (radial glia)，オリゴニューロン前駆細胞 (oligoneuronal precursors), ニューロン前駆細胞(neuronal precursors), 神経上皮/神経堤前駆細胞 (neuroepithelial/neural crest precursor)，星状細胞前駆体（astrocyte precursors）の 5 つのサブタイプに分かれ，TCGA サブタイプ (proneural, classical, mesenchymal) と大方対応している ${ }^{12)}$ (Table 1). エピゲノムでもう1つ重要なものは，DNAメチレー ションである. DNAメチレーションは大腸がんで有名だ 
A

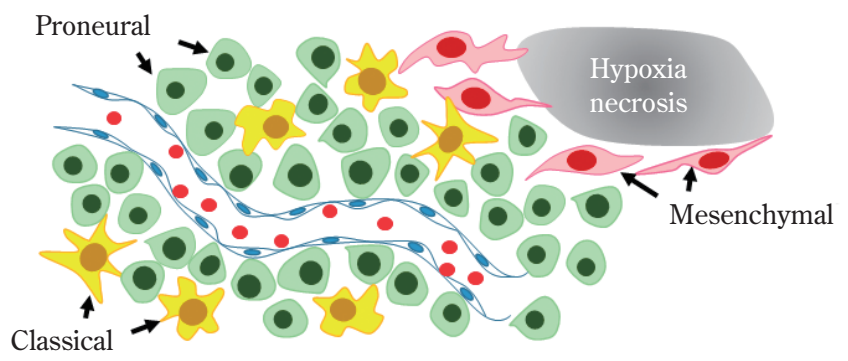

B

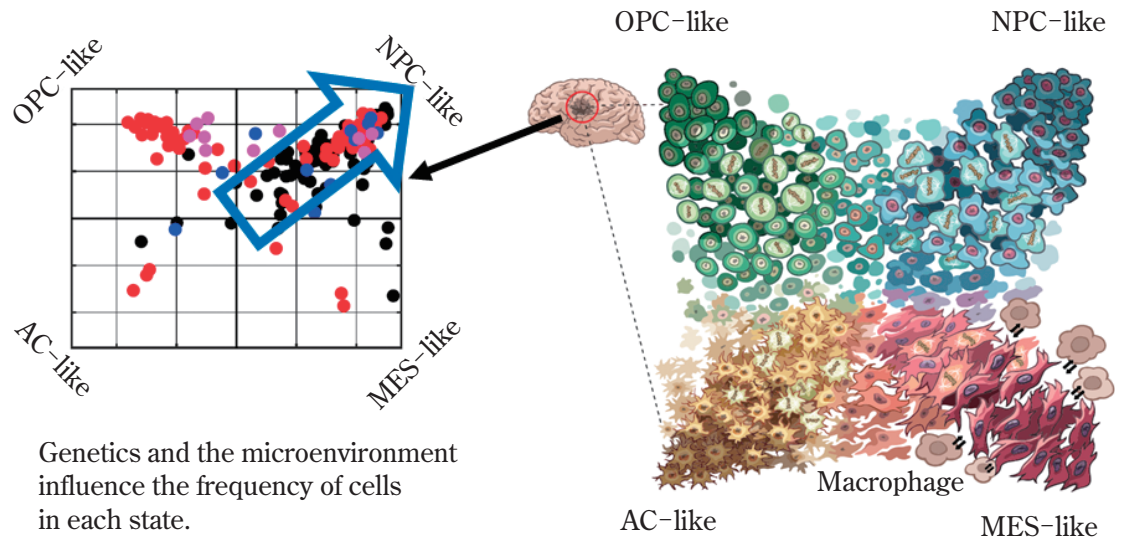

Fig. 1 Intratumoral heterogeneity and cellular transitions in glioblastomas

A : Illustration of glioblastoma with intratumoral heterogeneity. There are three cell subtypes of the same tumor.

B : Cell state plots and a model for the cellular states of glioblastoma and their genetic and micro-environmental determinants.

Mitotic spindles indicate cycling cells. Lighter or darker tones indicate the strength of each program. Intermediate states are shown between the four states and indicate transitions.

NPC-like : neural-progenitor-like, OPC-like : oligodendrocyte-progenitor-like, AC-like : astrocyte-like, MES-like : mesenchymal-like

(Cited from Neftel et al., 2019, Cell 178, modified. The figure was reprinted with permission from the publisher.)

が, 膠芽腫でも広範な DNA メチレーションを示す glioma CpG island hypermethylation phenotype (G-CIMP) が存 在することが明らかとなった ${ }^{23)}$.この G-CIMP は IDH変 異により誘導される ${ }^{35)}$. DNAメチレーションプロファイ ルにより, 膠芽腫は 6 つに分類され, TCGA サブタイプ に比較的よく合致する（Table 1)。 RTK1（PDGFRA）夕 イプ, RTK2 (classic) タイプ, mesenchymal タイプは, それぞれTCGAサブタイプの proneural, classical, mesenchymal に対応している。 そ水以外に, IDH変異夕イ プ, ヒストン H3G 34 変異夕イプ, ヒストン H $3 K 27$ 変異 タイプがあり, G-CIMP を示す IDH 変異タイプは TCGA サブタイプの proneural に合致するが，ヒストン H3G34 変異タイプ, ヒストン H $3 K 27$ 変異タイプは TCGAのサ ブタイプ分類にはあてはまらない ${ }^{33)}$. 特定の遺伝子変異 が特異な DNA メチレーションプロファイルを形成する
ことが明らかとなったことは大きな発見である。

\section{Single cell 解析による病態解明}

膠芽腫をはじめ，がんは 1 つの細胞の異常から生じ, 増殖して増大する。最初は起源が一緒でも増殖の段階で さまざまな異常が積み重なり, 不均一な腫瘍となる。以 前は組織を細胞集団でしか解析できなかったが, 最近は 組織の細胞を一つ一つ単離して, single cell の DNA, RNA を解析できるようになった ${ }^{26)}$. 膠芽腫における single cell 解析により, 同じ患者の膠芽腫組織でも EGFRや PDGFRの発現が細胞によってモザイク状に異なり，ま た, CD133 など幹細胞様の発現形態をもつ細胞から GFAP や Olig1 などの分化した細胞の発現形態をもつ細 胞まで，さまざまな分化度の細胞が勾配的に存在するこ とが明らかとなった ${ }^{24)}$ (Fig. 1A)。また, proneural タイプ 


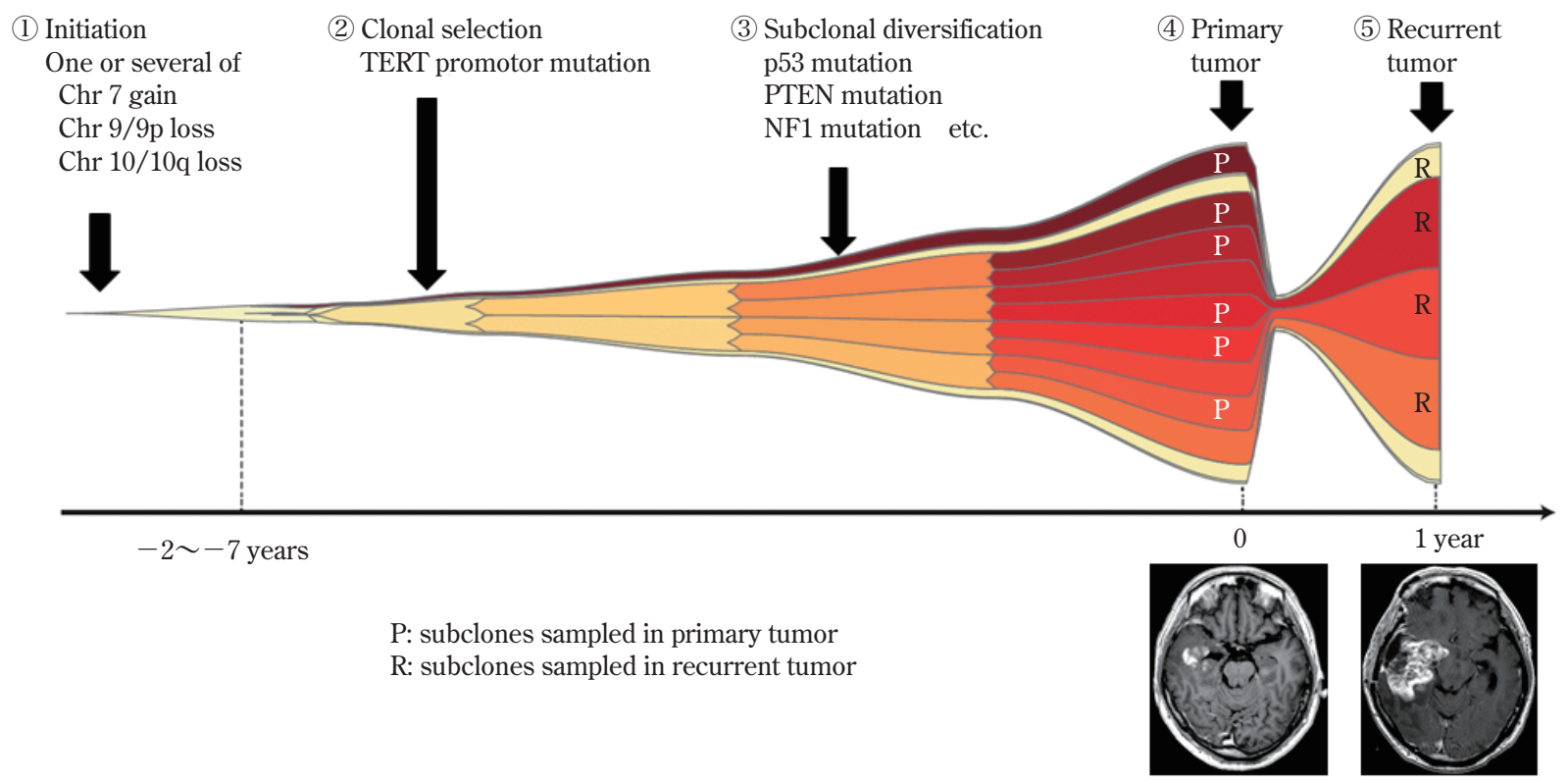

Fig. 2 Model of glioblastoma growth

Individual subclones are labeled by different shades of yellow to red for a clearer distinction. Chromosome number variations in chromosomes 7, 9, and 10 generally occur early in the evolution of the tumor, while TERT promoter mutations are often acquired subsequently in primary tumors, remaining subclonal in one-third of them. The absence of mutations that are characteristic of recurrent tumors may indicate that little directed selective pressure is exerted by chemotherapy and/or radiotherapy. The average division rate of the tumor cells was calculated by dividing the number of mutations occurring after primary resection by the mutation rate and the time between primary and secondary resection. This yielded a lower boundary for the tumor cell division rate of approximately once in 10 days. When the number of cell divisions is above that for establishing the primary tumor, then the founder cell will emerge approximately 2-7 years prior to diagnosis. This range indicates that IDHWT glioblastomas may undergo several years of evolution before being detected. (Cited from Verena Körber et al. Cancer Cell 35, 2019, modified. The figure was reprinted with permission from the publisher.)

や classical タイプの細胞は幹細胞様の発現形態をとるこ とが多い12).さらに，同一膠芽腫内には astrocyte-like, oligodendrocyte-progenitor-like, neural-progenitor-like, mesenchymal-likeのさまざまなサブタイプの細胞がハイ ブリッド状態で混在し，総和としてどのタイプヘベクト ルが向くかで総体的なサブタイプが決まる22) (Fig. 1B). また，個々の細胞のサブタイプも周囲の環境が変われば 別のサブタイプに変化する可塑性も有する ${ }^{22)}$. さらに, 胎児脳組織と膠芽腫組織の single cell RNA-seq を比較し た結果，両者は非常に類似しており，膠芽腫の個々の細 胞は胎児脳の glial progenitor cell, astrocyte, oligo-lineage cell, truncated radial glial cell, interneuron におよそ 対応していることが明らかとなった ${ }^{8)}$ ここれらの single cell の解析は，膠芽腫の病態を理解するうえで非常に強 い武器となり, 膠芽腫の動物モデルや新たな治療を考案 するうえで, とても重要なものとなると思われる。

\section{4 縦断的解析による病態解明}

治療の前後あるいは初発時と再発時など，時間軸によ る膠芽腫の変化について詳細に解析することで, 膠芽腫 の発生や悪性化の過程が明らかとなる。このような解析 により, Körber ら ${ }^{15)}$ は発症の $2 \sim 7$ 年前に 7 番染色体の 獲得， 9 番染色体 (短腕) の喪失， 10 番染色体（長腕） の欠失がまず起こり，その後，TERT のプロモーター変 異が生じて clonal selection が起こり, その後, p53やNF1 などの異常による多様化により急速に増大するモデルを 提唱した（Fig. 2)。また，初発時と再発時の変異パ夕ー ンは大方同様であって, 再発時に共通の変異は認めな かった ${ }^{15)}$ ，再発膠芽腫の発生モデルとしては，治療によ るフィルター作用で, 線形的 (linear), 分枝的 (branching), 祖先的（ancestral）進化に分けられ，サブクロー ンは遺伝子変異や染色体外 DNA によって特徴づけられ るとのモデルも提唱されている7). 再発時には proneural タイプから mesenchymal タイプに移行しやすく, ミクロ グリアやマクロファージの浸潤が増加するとの報告もあ 


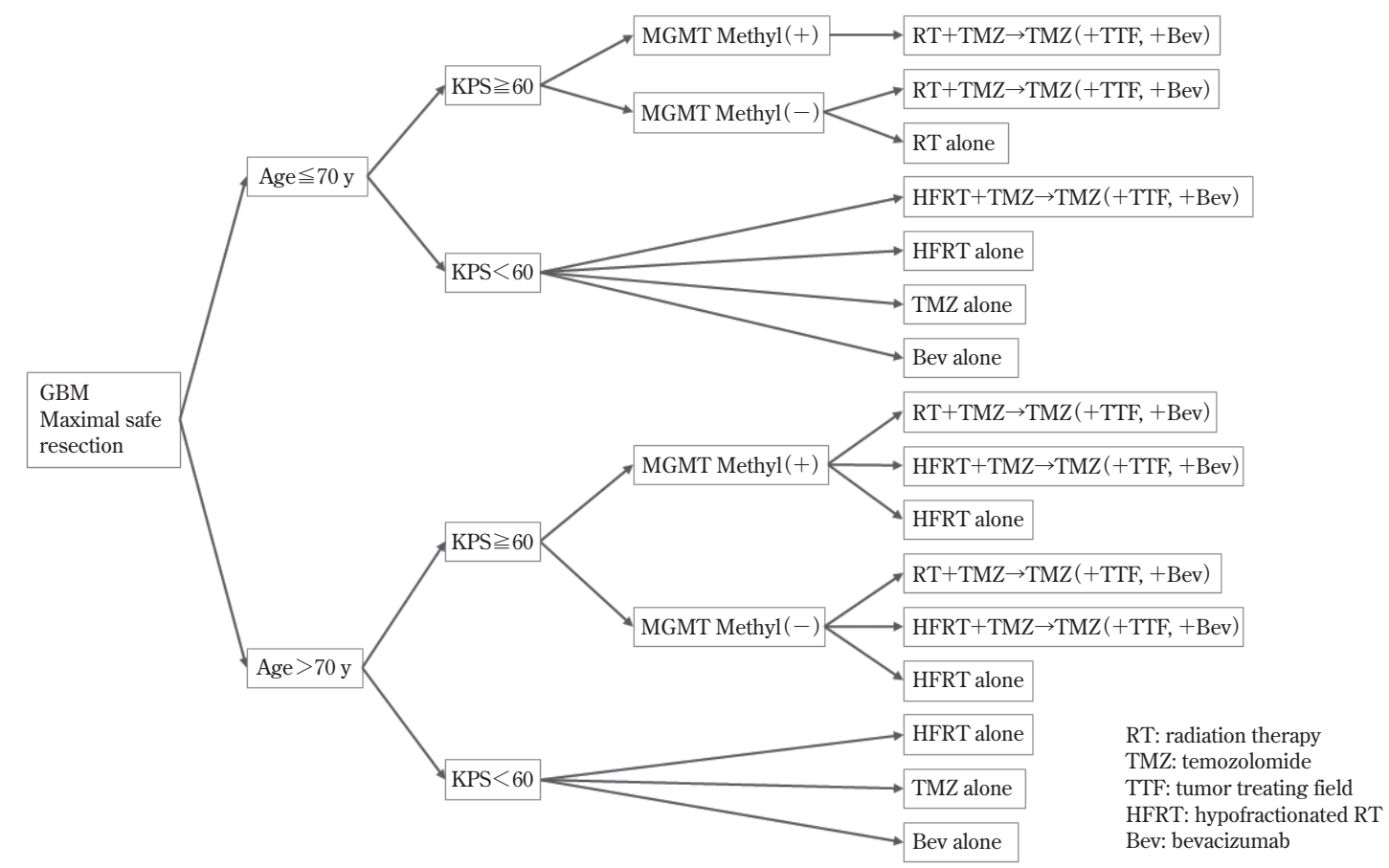

Fig. 3 Flow chart for the current treatment of newly diagnosed glioblastoma (modified NCCN guidelines ver. 3, 2020)

るが，まだまだ不明な点も多( ${ }^{116)}$. Wang $ら^{40)}$ は膠芽腫 91 例で初発と再発の組織のサブタイプを解析し，45\%で サブタイプのスイッチを認めたが, mesenchymalへの移 行は優位ではなかったと報告している。一方，NF1 遺伝 子異常は再発時のミクログリア/マクロファージの増加 と関連しており, 再発時の hypermutation は $\mathrm{CD}^{+} \mathrm{T}$ 細 胞の浸潤量と関連し，放射線治療後の早期の再発は免疫 抑制作用のある M2 マクロファージの浸潤量と関係して いた ${ }^{40)}$. DNAメチル化についても再発時腫瘍で脱メチル 化やメチル化の変化を認めたが, Wnt シグナル分子や T 細胞活性化が DNA メチル化の喪失と関係し，それらが 予後とも相関していることが判明した ${ }^{14)}$ 。 今後, 時間軸 を考慮した膠芽腫の変化は, 上記の single cell 解析を駆 使することで，さらに膠芽腫のダイナミックな変化が解 明されていくことと思わ机る。

\section{膠芽腫の治療 現在の標準治療一Multimodality Approach-}

最新の National Comprehensive Cancer Network ガイド ラインに基づく治療法のアルゴリズムを Fig. 3 に示す. 初発膠芽腫では, 年齢, KPS などの ADL の状態, MGMT
プロモーターメチレーションなどを考慮して，個々の患 者ごとに治療法を選択する，膠芽腫の標準治療は，2005 年に発表された第 3 相試験に基づいて，放射線療法（60 Gy）と同時併用のテモゾロミドおよびテモゾロミド維持 療法である (Stupp レジメン) ${ }^{31}$ 。電場療法 (tumor-treating field：TTF）は，トランスデューサーアレイで低電場 を頭部にかけることで腫瘍細胞の有糸分裂を阻害する新 しい治療法である。第 3 相試験では全生存期間 (OS) に 関して, Stupp レジメンのみでは中央值が 16 カ月であっ たものが, Stupp+TTF では 20.9 カ月と，有意に生存期 間が延長した (HR, $0.63 ; 95 \% \mathrm{CI}, 0.53-0.76[\mathrm{p}<.001])^{32)}$. TTF はこれまでの抗がん剤，分子標的治療薬とは異な り，全身性の副作用は少ないものの，頭部にアレイを装 着し長時間バッテリーにつないで生活しなくてはなら ず，生活の制限や外見に対する精神的苦痛への対応も重 要な課題である。手術に関しては，安全な可及的最大限 の切除 (gross total resection：GTR) が推奨されている. 最大限の摘出と神経学的な手術合併症の出現は背中合わ せであり，膠芽腫手術の最も難しい問題である。アミノ レブリン酸（5-ALA）を用いた術中蛍光診断による手術 の無作為化前方視試験は, 予想どおり PFS の改善を示し た ${ }^{30)}$. 65 歳以下の $I D H$ wild-type の膠芽腫では，FLAIR high の非造影病変を含めた supratotal resection を推奨す 


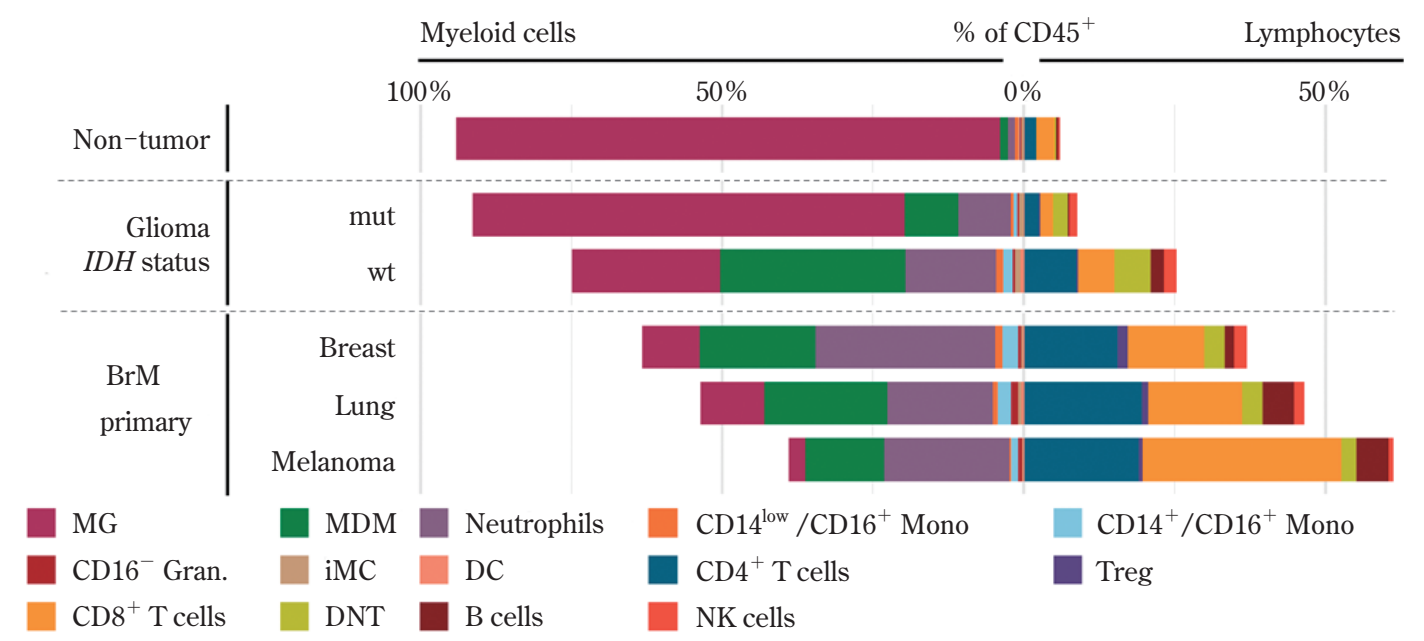

Fig. 4 Infiltrating immune cells in brain malignancies

The mean of the immune cell populations in non-tumor tissue $(n=6)$, gliomas ( $\mathrm{IDH}$ mut $=$ $17, \mathrm{n}$ IDH WT $=40$ ), and BrMs ( $\mathrm{n}$ breast $=13$, $\mathrm{n}$ lung $=16, \mathrm{n}$ melanoma $=8$ ) as percentages of $\mathrm{CD} 45^{+}$cells, revealing disease- ${ }^{-}$specific enrichment of immune cells with pronounced differences in the proportional abundance of tissue-resident microglia, infiltrating monocyte-derived macrophages, neutrophils, and $\mathrm{T}$ cells.

MG : microglia, MDM : monocyte-derived macrophages, DC : dendritic cells, Treg : regulatory T cells, DNT : double-negative T cells (Cited from Klemm et al., 2020, Cell 181, modified. The figure was reprinted with permission from the publisher.)

る報告もあるが21), 神経学的後遺症を残さず安全に supratotal resection 可能な症例は, きわめて少ない症例 に限られる。一方, 脳神経外科医としては, 神経学的後 遺症を残さず安全に摘出できるのであれば，そのような 症例は逃さず手術しなければならない。 また，術中局所 療法であるカルムスチン脳内留置用剤は生存期間を改善 したと後方視的解析で報告されているが，現在 JCOGで 第 3 相の臨床試験が ongoing 中であり, その結果が待た れるところである。ベバシズマブは VEGFに対するヒト 化モノクローナル抗体で，血管新生を阻害するが，初発 の膠芽腫に投与可能なのは日本のみである. KPS の不良 な初発脍芽腫患者に初期治療からベバシズマブを投与す ると KPS が改善し, 治療可能な期間も延長することで, 予後が改善することを経験する。したがって, ベバシズ マブの使用法, 投与患者の選択にはまだまだ検討する余 地があると思われる。

\section{今後の治療一免疫療法について一}

脳は免疫特権領域（immune-privileged site）であると 長い間考えられてきたが，脳における免疫監視と骨䯣系 細胞の役割は, 従来考えられていた以上に複雑であるこ とがわかってきた ${ }^{1927)}$. 硬膜静脈洞に並行してリンパ管
が走行しており，脳内の抗原提示細胞が免疫応答のた め, 深部額部リンパ節へ移動する ${ }^{17)}$. 腫瘍内にはさまざ まな免疫細胞がみられるが, 腫瘍内に浸潤する免疫細胞 の種類，量，比率は脳腫瘍によってさまざまで，膠芽腫 では単球由来のマクロファージが多く, リンパ球が比較 的少ない ${ }^{13)}{ }^{19)}$ (Fig. 4)。また, 膠芽腫はSTAT3 経路や IDO （indoleamine 2,3-dioxygenase）酵素など，免疫応答を抑 制するシグナル伝達経路が充進している ${ }^{17) 399}$ 。外科手 術，放射線療法，テモゾロミド化学療法，およびコルチ コステロイドによる標準療法はすべて免疫系に強い影響 を及ぼすと考元られ，免疫療法を施行するうえで考慮す べき課題である.

自家腫瘍組織を使用して腫瘍抗原を生成する樹状細胞 ワクチン（DCVax-L）の第 3 相試験では生存期間中央值 で 34.7 力月， 3 年生存率 $46.4 \%$ と初期の報告でいわれて おり，今後の結果が期待される ${ }^{18)}$ 。また，日本でも自家 腫瘍ワクチンの臨床試験が行われており，その結果も期 待されるところである。免疫チェックポイント阻害剤 は，他がん腫に括いては非常に奏効する抗がん剂である が，膠芽腫ではまだ有用な効果は認められていない，再 発性膠芽腫において, PD1 阻害剤であるニボルマブと血 管新生阻害剤であるべバシズマブを比較した第 3 相試験 では，生存期間に改善はみられなかった ${ }^{28)}$. 初発膠芽腫 
Longitudinal analysis

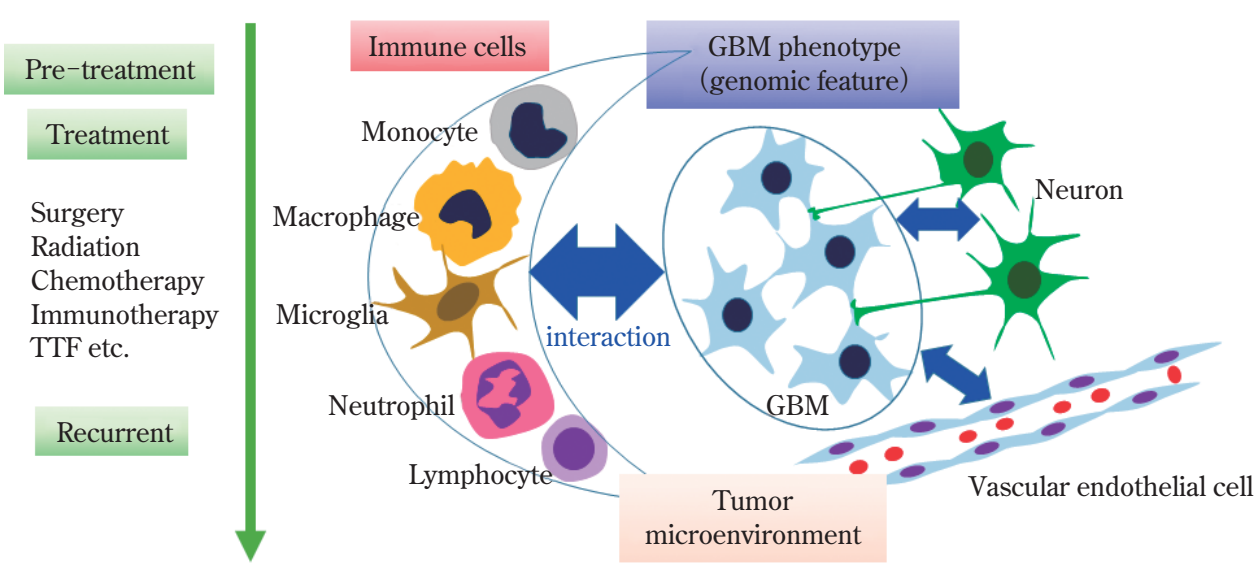

Fig. 5 Treatment target after considering the heterogeneity of glioblastoma cells and the immune microenvironment

It is necessary to analyze the biological characteristics of the glioblastoma cells themselves. However, as a direction for future research, the interaction between glioblastoma cells and various cells that form the microenvironment needs to be analyzed, that is, immune cells such as macrophages/microglia and lymphocytes, vascular endothelial cells, and neurons, need to be considered in terms of the time axis.

に対するニボルマブの第 3 相試験が施行されているが, MGMTメチル化陰性の初発膠芽腫においてはニボルマ ブの有効性は証明できなかった。 MGMTメチル化陽性 の初発膠芽腫に対しては現在解析中であり, 結果が待た れるところである。一方, PD1 阻害剤を術前にネオア ジュバントとして投与すると奏効する可能性があること が最近報告された ${ }^{6) 29)}$. 術前に投与することで, $\mathrm{T}$ 細胞 の活性化とクローナルセレクションのみでなくインター フェロンの下流分子の発現が充進して細胞周期関連分子 が抑制される。また, PD1 阻害剤に抵抗性の膠芽腫は免 疫抑制が強く, PTEN 変異と関係するとの報告もあ る ${ }^{41)}$. 遺伝子改変 $\mathrm{T}$ 細胞を用いたキメラ抗原受容体 (CAR) $\mathrm{T}$ 細胞療法も今後を期待されている免疫療法の 1 つであり, 現在研究が進められている2).これまでのと ころ IL13R $\alpha 2$, EGFRvIII や HER2 などをターゲットと した CAR-Tが開発されてきたが，新たなターゲットと して EphA2 やB7-H3 や CD133なども開発されており, multi-target の CAR-Tも新たな治療法として注目されて いる ${ }^{34)}$.

\section{未来医療を見据えた研究の方向性 一腫瘍の不均一性と免疫微小環境一}

これまでの精力的な遺伝子, 染色体, エピゲノム研究 で，膠芽腫細胞の性質はかなり明らかになり，遺伝子異 常を標的としたさまざまな分子標的治療薬が開発されて
きた。膠芽腫で最も高頻度に異常を認めるEGFR や mTOR をターゲットとした分子標的治療薬は，残念なが ら有効性を得ることはできなかった $\left.{ }^{20)} 25\right)$.がんゲノム医 療は個々のがんの遺伝子異常に合わせて治療を行う医療 で, precision medicine（精密医療）ともいわれている. がんゲノム医療を進めるにあたり，がん組織を用いたが ん遺伝子パネル検査が保険診療として認められるように なった. 現在は, Foundation-1 と NCC オンコパネルの 2 種類が保険適応となっており, 膠芽腫の遺伝子異常を網 羅的に解析できる. 今後他のがんパネル検査も保険適応 となり，がんゲノム医療はますます盛んになるものと思 われる。しかし，このがん遺伝子パネル検査は，がんの 一部の組織を用いた遺伝子検査であり，がんの不均一 性, 可塑性, 治療後の変化に対しては対応できていない 点が問題である.

今後の膠芽腫研究は, 膠芽腫細胞を取り巻く細胞の解 析および相互作用が重要になると思われる．特に免疫細 胞に関しては, 膠芽腫ごとに異なり, 膠芽腫の遺伝子異 常とも関連し，個々の免疫微小環境を形成しているもの と思われる (Fig. 5). 膠芽腫細胞は免疫チェックポイン トをすり抜け，免疫監視を免れて，免疫抑制環境の中で 免疫細胞を自分の成長に都合のよいように利用している ものと思われる。特にマクロファージは免疫抑制性サイ トカインを産生し, 膠芽腫を免疫細胞から守り,さらに 増殖や浸潤，血管新生をサポートしている。われわれの 研究では, 浸潤しているマクロファージが多い膠芽腫の 
ほうが浸潤が少ない膠芽腫に比べて予後不良であった。 さらに, 膠芽腫患者の随液を膠芽腫培養細胞に加えて遊 走能を調べると, 髄液を加えない細胞に比べて遊走能が 格段に充進した ${ }^{11)}$. 免疫細胞をはじめとするさまざまな 細胞が分泌する液性因子は膠芽腫の性質を変えるため, これらを把握して治療に臨まなければならない。また， 免疫細胞などから分泌された DNA や mRNA, miRNA な ぞを含んだエクソソームも膠芽腫細胞に作用する。一 方, 神経細胞との関係にも留意する必要がある。神経細 胞が分泌する neuroligin-3 が mTOR を活性化させて膠芽 腫細胞の増殖を促進させることがわかっている ${ }^{36)}$. ま た，神経がグリオーマ細胞と神経-グリオーマシナプス を形成し, 神経細胞の活動によりシナプスが活性化して グリオーマ細胞の増殖や浸潤が促進されることが報告さ れた ${ }^{37)}$ 。このように, 膠芽腫細胞を取り巻くさまざまな 細胞は，相互に影響し合っているのである。この相互作 用は治療を行うことでまた劇的に変化する。 ステロイド や抗がん剂は免疫を抑制させ，血管新生阻害剤や放射線 治療は腫瘍の血流を変化させ，代謝のリモデリングを誘 発させる、さまざまな治療に伴う微小環境の変化を詳細 に解析し, 膠芽腫を包括的に理解することが膠芽腫克服 のためには必要と考える。

\section{結 語}

悪性腫瘍の中でも最も悪性の部類に入る膠芽腫につい て, 染色体・遺伝子異常, エピゲノムによる分類, single cell での性質, 縦断的解析による発生, 進化の形態につ いて解説した。 また, 今後期待される免疫療法について, これまでの臨床試験の結果を提示して解説した。技術の 進歩とともに，膠芽腫の性質は徐々に解明されつつあ る。今後, $\mathrm{AI}$ や新たな技術を駆使して膠芽腫を取り巻く 複雑な腫瘍微小環境のネットワークの全貌が解明される だろう。脳は人の個性を作り精神が宿る臓器であるがゆ え, 機能を温存しながら治療することは至難の業である が，ブレークスルーが訪れることを期待したい.

著者全員は日本脳神経外科学会への COI 自己申告の登録を 完了しています。

本論文に関して開示すべき COI はありません.

\section{文 献}

1) Bhat KPL, Balasubramaniyan V, Vaillant B, Ezhilarasan R, Hummelink K, Hollingsworth F, Wani K, Heathcock L, James JD, Goodman LD, Conroy S, Long L, Lelic N, Wang S,
Gumin J, Raj D, Kodama Y, Raghunathan A, Olar A, Joshi K, Pelloski CE, Heimberger A, Kim SH, Cahill DP, Rao G, Den Dunnen WFA, Boddeke HWGM, Phillips HS, Nakano I, Lang FF, Colman H, Sulman EP, Aldape K : Mesenchymal differentiation mediated by $\mathrm{NF}-\mathrm{kappaB}$ promotes radiation resistance in glioblastoma. Cancer Cell 24:331-346, 2013.

2) Brown CE, Alizadeh D, Starr R, Weng L, Wagner JR, Naranjo A, Ostberg JR, Blanchard MS, Kilpatrick J, Simpson J, Kurien A, Priceman SJ, Wang X, Harshbarger TL, D’Apuzzo M, Ressler JA, Jensen MC, Barish ME, Chen M, Portnow J, Forman SJ, Badie B : Regression of Glioblastoma after Chimeric Antigen Receptor T-Cell Therapy. N Engl J Med $375:$ 2561-2569, 2016.

3) Cancer Genome Atlas Research Network: Comprehensive genomic characterization defines human glioblastoma genes and core pathways. Nature $455:$ 1061-1068, 2008.

4) Chan JA, Krichevsky AM, Kosik KS: MicroRNA-21 is an antiapoptotic factor in human glioblastoma cells. Cancer Res 65: 6029-6033, 2005.

5) Ciafrè SA, Galardi S, Mangiola A, Ferracin M, Liu CG, Sabatino G, Negrini M, Maira G, Croce CM, Farace MG : Extensive modulation of a set of microRNAs in primary glioblastoma. Biochem Biophys Res Commun 334:1351-1358, 2005.

6) Cloughesy TF, Mochizuki AY, Orpilla JR, Hugo W, Lee AH, Davidson TB, Wang AC, Ellingson BM, Rytlewski JA, Sanders CM, Kawaguchi ES, Du L, Li G, Yong WH, Gaffey SC, Cohen AL, Mellinghoff IK, Lee EQ, Reardon DA, O'Brien BJ, Butowski NA, Nghiemphu PL, Clarke JL, ArrillagaRomany IC, Colman H, Kaley TJ, de Groot JF, Liau LM, Wen PY, Prins RM : Neoadjuvant anti-PD-1 immunotherapy promotes a survival benefit with intratumoral and systemic immune responses in recurrent glioblastoma. Nat Med $25: 477-486,2019$.

7) GLASS Consortium : Glioma through the looking GLASS : molecular evolution of diffuse gliomas and the Glioma Longitudinal Analysis Consortium. Neuro Oncol 20:873-884, 2018.

8) Couturier CP, Ayyadhury S, Le PU, Nadaf J, Monlong J, Riva G, Allache R, Baig S, Yan X, Bourgey M, Lee C, Wang YCD, Wee Yong V, Guiot MC, Najafabadi H, Misic B, Antel J, Bourque G, Ragoussis J, Petrecca K : Single-cell RNA-seq reveals that glioblastoma recapitulates a normal neurodevelopmental hierarchy. Nat Commun $\quad$ 11:3406, 2020.

9) Hanahan D, Weinberg RA: The hallmarks of cancer. Cell $100: 57-70,2000$.

10) Hanahan D, Weinberg RA : Hallmarks of cancer : the next generation. Cell 144: 646-674, 2011.

11) Hori T, Sasayama T, Tanaka K, Koma YI, Nishihara M, Tanaka H, Nakamizo S, Nagashima H, Maeyama M, Fujita Y, Yokozaki H, Hirose T, Kohmura E : Tumor-associated macrophage related interleukin -6 in cerebrospinal fluid as a prognostic marker for glioblastoma. J Clin Neurosci 68 : 281-289, 2019.

12) Kim TM, Huang W, Park R, Park PJ, Johnson MD : A developmental taxonomy of glioblastoma defined and maintained by MicroRNAs. Cancer Res $\quad$ 71:3387-3399, 2011.

13) Klemm F, Maas RR, Bowman RL, Kornete M, Soukup K, Nassiri S, Brouland JP, Iacobuzio-Donahue CA, Brennan C, Tabar V, Gutin PH, Daniel RT, Hegi ME, Joyce JA : Interrogation of the microenvironmental landscape in brain tumors 
reveals disease-specific alterations of immune cells. Cell 181 : 1643-1660 e17, 2020.

14) Klughammer J, Kiesel B, Roetzer T, Fortelny N, Nemc A, Nenning KH, Furtner J, Sheffield NC, Datlinger P, Peter N, Nowosielski M, Augustin M, Mischkulnig M, Ströbel T, Alpar D, Ergüner B, Senekowitsch M, Moser P, Freyschlag CF, Kerschbaumer J, Thomé C, Grams AE, Stockhammer G, Kitzwoegerer M, Oberndorfer S, Marhold F, Weis S, Trenkler J, Buchroithner J, Pichler J, Haybaeck J, Krassnig S, Mahdy Ali K, von Campe G, Payer F, Sherif C, Preiser J, Hauser T, Winkler PA, Kleindienst W, Würtz F, BrandnerKokalj T, Stultschnig M, Schweiger S, Dieckmann K, Preusser M, Langs G, Baumann B, Knosp E, Widhalm G, Marosi C, Hainfellner JA, Woehrer A, Bock C: The DNA methylation landscape of glioblastoma disease progression shows extensive heterogeneity in time and space. Nat Med 24: 1611-1624, 2018.

15) Körber V, Yang J, Barah P, Wu Y, Stichel D, Gu Z, Fletcher MNC, Jones D, Hentschel B, Lamszus K, Tonn JC, Schackert G, Sabel M, Felsberg J, Zacher A, Kaulich K, Hübschmann D, Herold-Mende C, von Deimling A, Weller M, Radlwimmer B, Schlesner M, Reifenberger G, Höfer T, Lichter P : Evolutionary trajectories of IDH (WT) glioblastomas reveal a common path of early tumorigenesis instigated years ahead of initial diagnosis. Cancer Cell 35 : 692-704 e12, 2019.

16) Kwon SM, Kang SH, Park CK, Jung S, Park ES, Lee JS, Kim $\mathrm{SH}$, Woo HG : Recurrent glioblastomas reveal molecular subtypes associated with mechanistic implications of drugresistance. PLoS One 10: e0140528, 2015.

17) Li B, Severson E, Pignon JC, Zhao H, Li T, Novak J, Jiang P, Shen H, Aster JC, Rodig S, Signoretti S, Liu JS, Liu XS : Comprehensive analyses of tumor immunity: implications for cancer immunotherapy. Genome Biol 17 : 174, 2016.

18) Liau LM, Ashkan K, Tran DD, Campian JL, Trusheim JE, Cobbs CS, Heth JA, Salacz M, Taylor S, D'Andre SD, Iwamoto FM, Dropcho EJ, Moshel YA, Walter KA, Pillainayagam CP, Aiken R, Chaudhary R, Goldlust SA, Bota DA, Duic P, Grewal J, Elinzano H, Toms SA, Lillehei KO, Mikkelsen T, Walbert T, Abram SR, Brenner AJ, Brem S, Ewend MG, Khagi S, Portnow J, Kim LJ, Loudon WG, Thompson RC, Avigan DE, Fink KL, Geoffroy FJ, Lindhorst S, Lutzky J, Sloan AE, Schackert G, Krex D, Meisel HJ, Wu J, Davis RP, Duma C, Etame AB, Mathieu D, Kesari S, Piccioni D, Westphal M, Baskin DS, New PZ, Lacroix M, May SA, Pluard TJ, Tse V, Green RM, Villano JL, Pearlman M, Petrecca K, Schulder M, Taylor LP, Maida AE, Prins RM, Cloughesy TF, Mulholland P, Bosch ML : First results on survival from a large Phase 3 clinical trial of an autologous dendritic cell vaccine in newly diagnosed glioblastoma. J Transl Med 16: 142, 2018.

19) Louveau A, Smirnov I, Keyes TJ, Eccles JD, Rouhani SJ, Peske JD, Derecki NC, Castle D, Mandell JW, Lee KS, Harris TH, Kipnis J : Structural and functional features of central nervous system lymphatic vessels. Nature $\quad 523: 337-$ $341,2015$.

20) Ma DJ, Galanis E, Anderson SK, Schiff D, Kaufmann TJ, Peller PJ, Giannini C, Brown PD, Uhm JH, McGraw S, Jaeckle KA, Flynn PJ, Ligon KL, Buckner JC, Sarkaria JN : A phase II trial of everolimus, temozolomide, and radiotherapy in patients with newly diagnosed glioblastoma : NCCTG N057K. Neuro Oncol 17:1261-1269, 2015.
21) Molinaro AM, Hervey-Jumper S, Morshed RA, Young J, Han SJ, Chunduru P, Zhang Y, Phillips JJ, Shai A, Lafontaine M, Crane J, Chandra A, Flanigan P, Jahangiri A, Cioffi G, Ostrom Q, Anderson JE, Badve C, Barnholtz-Sloan J, Sloan AE, Erickson BJ, Decker PA, Kosel ML, LaChance D, Eckel-Passow J, Jenkins R, Villanueva-Meyer J, Rice T, Wrensch M, Wiencke JK, Oberheim Bush NA, Taylor J, Butowski N, Prados M, Clarke J, Chang S, Chang E, Aghi M, Theodosopoulos P, McDermott M, Berger MS : Association of maximal extent of resection of contrast-enhanced and non-contrast-enhanced tumor with survival within molecular subgroups of patients with newly diagnosed glioblastoma. JAMA Oncol $\mathbf{6}:$ 495-503, 2020.

22) Neftel C, Laffy J, Filbin MG, Hara T, Shore ME, Rahme GJ, Richman AR, Silverbush D, Shaw ML, Hebert CM, Dewitt J, Gritsch S, Perez EM, Gonzalez Castro LN, Lan X, Druck N, Rodman C, Dionne D, Kaplan A, Bertalan MS, Small J, Pelton K, Becker S, Bonal D, Nguyen QD, Servis RL, Fung JM, Mylvaganam R, Mayr L, Gojo J, Haberler C, Geyeregger R, Czech T, Slavc I, Nahed BV, Curry WT, Carter BS, Wakimoto H, Brastianos PK, Batchelor TT, StemmerRachamimov A, Martinez-Lage M, Frosch MP, Stamenkovic I, Riggi N, Rheinbay E, Monje M, Rozenblatt-Rosen O, Cahill DP, Patel AP, Hunter T, Verma IM, Ligon KL, Louis DN, Regev A, Bernstein BE, Tirosh I, Suvà ML : An integrative model of cellular states, plasticity, and genetics for glioblastoma. Cell 178: 835-49 e21, 2019.

23) Noushmehr H, Weisenberger DJ, Diefes K, Phillips HS, Pujara K, Berman BP, Pan F, Pelloski CE, Sulman EP, Bhat KP, Verhaak RG, Hoadley KA, Hayes DN, Perou CM, Schmidt HK, Ding L, Wilson RK, Van Den Berg D, Shen H, Bengtsson H, Neuvial P, Cope LM, Buckley J, Herman JG, Baylin SB, Laird PW, Aldape K ; Cancer Genome Atlas Research Network: Identification of a $\mathrm{CpG}$ island methylator phenotype that defines a distinct subgroup of glioma. Cancer Cell $17: 510-522,2010$.

24) Patel AP, Tirosh I, Trombetta JJ, Shalek AK, Gillespie SM, Wakimoto H, Cahill DP, Nahed BV, Curry WT, Martuza RL, Louis DN, Rozenblatt-Rosen O, Suvà ML, Regev A, Bernstein BE : Single-cell RNA-seq highlights intratumoral heterogeneity in primary glioblastoma. Science $\mathbf{3 4 4}$ : 1396-1401, 2014.

25) Peereboom DM, Shepard DR, Ahluwalia MS, Brewer CJ, Agarwal N, Stevens GH, Suh JH, Toms SA, Vogelbaum MA, Weil RJ, Elson P, Barnett GH : Phase II trial of erlotinib with temozolomide and radiation in patients with newly diagnosed glioblastoma multiforme. J Neurooncol $\mathbf{9 8 : 9 3 -}$ 99, 2010.

26) Ramsköld D, Luo S, Wang YC, Li R, Deng Q, Faridani OR, Daniels GA, Khrebtukova I, Loring JF, Laurent LC, Schroth GP, Sandberg R : Full-length mRNA-Seq from single-cell levels of RNA and individual circulating tumor cells. Nat Biotechnol 30:777-782, 2012.

27) Ransohoff RM, Engelhardt B : The anatomical and cellular basis of immune surveillance in the central nervous system. Nat Rev Immunol 12 : 623-635, 2012.

28) Reardon DA, Brandes AA, Omuro A, Mulholland P, Lim M, Wick A, Baehring J, Ahluwalia MS, Roth P, Bähr O, Phuphanich S, Sepulveda JM, De Souza P, Sahebjam S, Carleton M, Tatsuoka K, Taitt C, Zwirtes R, Sampson J, Weller $\mathrm{M}$ : Effect of nivolumab vs bevacizumab in patients with recurrent glioblastoma: The CheckMate 143 phase 3 ran- 
domized clinical trial. JAMA Oncol $\quad 6$ : 1003-1010, 2020.

29) Schalper KA, Rodriguez-Ruiz ME, Diez-Valle R, LópezJaneiro A, Porciuncula A, Idoate MA, Inogés S, de Andrea C, López-Diaz de Cerio A, Tejada S, Berraondo P, VillarroelEspindola F, Choi J, Gúrpide A, Giraldez M, Goicoechea I, Gallego Perez-Larraya J, Sanmamed MF, Perez-Gracia JL, Melero I: Neoadjuvant nivolumab modifies the tumor immune microenvironment in resectable glioblastoma. Nat Med 25: 470-476, 2019.

30) Stummer W, Pichlmeier U, Meinel T, Wiestler OD, Zanella F, Reulen HJ ; ALA-Glioma Study Group : Fluorescenceguided surgery with 5 -aminolevulinic acid for resection of malignant glioma : a randomised controlled multicentre phase III trial. Lancet Oncol $\quad 7: 392-401,2006$.

31) Stupp R, Mason WP, van den Bent MJ, Weller M, Fisher B, Taphoorn MJ, Belanger K, Brandes AA, Marosi C, Bogdahn U, Curschmann J, Janzer RC, Ludwin SK, Gorlia T, Allgeier A, Lacombe D, Cairncross JG, Eisenhauer E, Mirimanoff RO ; European Organisation for Research and Treatment of Cancer Brain Tumor and Radiotherapy Groups ; National Cancer Institute of Canada Clinical Trials Group : Radiotherapy plus concomitant and adjuvant temozolomide for glioblastoma. N Engl J Med 352 : 987-996, 2005.

32) Stupp R, Taillibert S, Kanner AA, Kesari S, Steinberg DM, Toms SA, Taylor LP, Lieberman F, Silvani A, Fink KL, Barnett GH, Zhu JJ, Henson JW, Engelhard HH, Chen TC, Tran DD, Sroubek J, Tran ND, Hottinger AF, Landolfi J, Desai R, Caroli M, Kew Y, Honnorat J, Idbaih A, Kirson ED, Weinberg U, Palti Y, Hegi ME, Ram Z: Maintenance therapy with tumor-treating fields plus temozolomide vs temozolomide alone for glioblastoma : a randomized clinical trial. JAMA 314: 2535-2543, 2015.

33) Sturm D, Witt H, Hovestadt V, Khuong-Quang DA, Jones DT, Konermann C, Pfaff E, Tönjes M, Sill M, Bender S, Kool M, Zapatka M, Becker N, Zucknick M, Hielscher T, Liu XY, Fontebasso AM, Ryzhova M, Albrecht S, Jacob K, Wolter M, Ebinger M, Schuhmann MU, van Meter T, Frühwald MC, Hauch H, Pekrun A, Radlwimmer B, Niehues T, von Komorowski G, Dürken M, Kulozik AE, Madden J, Donson A, Foreman NK, Drissi R, Fouladi M, Scheurlen W, von Deimling A, Monoranu C, Roggendorf W, Herold-Mende C, Unterberg A, Kramm CM, Felsberg J, Hartmann C, Wiestler B, Wick W, Milde T, Witt O, Lindroth AM, Schwartzentruber J, Faury D, Fleming A, Zakrzewska M, Liberski PP, Zakrzewski K, Hauser P, Garami M, Klekner A, Bognar L, Morrissy S, Cavalli F, Taylor MD, van Sluis P, Koster J, Versteeg R, Volckmann R, Mikkelsen T, Aldape K, Reifenberger G, Collins VP, Majewski J, Korshunov A, Lichter P, Plass C, Jabado N, Pfister SM: Hotspot mutations in H3F3A and IDH1 define distinct epigenetic and biological subgroups of glioblastoma. Cancer Cell 22 : 425-437, 2012.

34) Tschernia NP, Khagi S : A Head Start : CAR-T Cell Therapy for primary malignant brain tumors. Curr Treat Options
Oncol 21: 73, 2020.

35) Turcan S, Rohle D, Goenka A, Walsh LA, Fang F, Yilmaz E, Campos C, Fabius AW, Lu C, Ward PS, Thompson CB, Kaufman A, Guryanova O, Levine R, Heguy A, Viale A, Morris LG, Huse JT, Mellinghoff IK, Chan TA：IDH1 mutation is sufficient to establish the glioma hypermethylator phenotype. Nature 83:479-483, 2012 ; .

36) Venkatesh HS, Johung TB, Caretti V, Noll A, Tang Y, Nagaraja S, Gibson EM, Mount CW, Polepalli J, Mitra SS, Woo PJ, Malenka RC, Vogel H, Bredel M, Mallick P, Monje M : Neuronal activity promotes glioma growth through neuroligin -3 secretion. Cell 161:803-816, 2015.

37) Venkatesh HS, Morishita W, Geraghty AC, Silverbush D, Gillespie SM, Arzt M, Tam LT, Espenel C, Ponnuswami A, Ni L, Woo PJ, Taylor KR, Agarwal A, Regev A, Brang D, Vogel H, Hervey-Jumper S, Bergles DE, Suvà ML, Malenka $\mathrm{RC}$, Monje $\mathrm{M}$ : Electrical and synaptic integration of glioma into neural circuits. Nature $\mathbf{5 7 3}: 539-545,2019$.

38) Verhaak RG, Hoadley KA, Purdom E, Wang V, Qi Y, Wilkerson MD, Miller CR, Ding L, Golub T, Mesirov JP, Alexe G, Lawrence M, O’Kelly M, Tamayo P, Weir BA, Gabriel S, Winckler W, Gupta S, Jakkula L, Feiler HS, Hodgson JG, James CD, Sarkaria JN, Brennan C, Kahn A, Spellman PT, Wilson RK, Speed TP, Gray JW, Meyerson M, Getz G, Perou CM, Hayes DN; Cancer Genome Atlas Research Network: Integrated genomic analysis identifies clinically relevant subtypes of glioblastoma characterized by abnormalities in PDGFRA, IDH1, EGFR, and NF1. Cancer Cell 17 : 98-110, 2010

39) Wainwright DA, Chang AL, Dey M, Balyasnikova IV, Kim CK, Tobias A, Cheng Y, Kim JW, Qiao J, Zhang L, Han Y, Lesniak MS : Durable therapeutic efficacy utilizing combinatorial blockade against IDO, CTLA-4, and PD-L1 in mice with brain tumors. Clin Cancer Res 20:5290-5301, 2014.

40) Wang Q, Hu B, Hu X, Kim H, Squatrito M, Scarpace L, deCarvalho AC, Lyu S, Li P, Li Y, Barthel F, Cho HJ, Lin YH, Satani N, Martinez-Ledesma E, Zheng S, Chang E, Sauvé CG, Olar A, Lan ZD, Finocchiaro G, Phillips JJ, Berger MS, Gabrusiewicz KR, Wang G, Eskilsson E, Hu J, Mikkelsen T, DePinho RA, Muller F, Heimberger AB, Sulman EP, Nam $\mathrm{DH}$, Verhaak RGW : Tumor evolution of glioma-intrinsic gene expression subtypes associates with immunological changes in the microenvironment. Cancer Cell $32: 42-56$ e6, 2017.

41) Zhao J, Chen AX, Gartrell RD, Silverman AM, Aparicio L, Chu T, Bordbar D, Shan D, Samanamud J, Mahajan A, Filip I, Orenbuch R, Goetz M, Yamaguchi JT, Cloney M, Horbinski C, Lukas RV, Raizer J, Rae AI, Yuan J, Canoll P, Bruce JN, Saenger YM, Sims P, Iwamoto FM, Sonabend AM, Rabadan $\mathrm{R}$ : Immune and genomic correlates of response to antiPD-1 immunotherapy in glioblastoma. Nat Med 25:462$469,2019$. 
膠芽腫の病態・治療と未来医療を見据えた研究の方向性

篠山 隆司＼cjkstart田中 一寛

膠芽腫細胞にはコア経路異常を軸として, proneural, classical, mesenchymal のサブタイプがある が, 遺伝子・染色体異常と腫瘍周囲の微小環境により可塑性を有する. また, 再発時には膠芽腫サブ タイプがスイッチされ, 異なった性質を獲得することも多い. 今後, 現在の標準治療に免疫療法など の新たな治療が加わってくると期待される. 膠芽腫細胞そのものの性質を理解することも必要だが, 腫瘍微小環境を形成する免疫細胞や血管内皮細胞, 神経細胞などと膠芽腫細胞との関係を, 治療前/ 治療後あるいは初発時/再発時などのように時間軸を考慮し, 縦断的に研究することが必要となろう.

脳外誌 $30 ： 380-390,2021$ 